\title{
Experimental design optimization and decolorization of an azo dye by cross-linked peroxidase aggregates
}

\author{
Oğuz Akpolat (iD 0000-0003-2220-4496 \\ Fatma Ayhan (iD 0000-0002-6623-4323 \\ Muğla Sttkı Koçman University, Faculty of Science, Department of Chemistry, Biochemistry Division, \\ Biochemistry\&Biomaterials Research Laboratory, 48000, Muğla, Turkey
}

Corresponding Author: Fatma Ayhan, fayhan@mu.edu.tr; fayhan@gmail.com

\begin{abstract}
Synthetic textile azo-dyes are important water contaminants in industrial textile wastes and peroxidases have potential for textile-dye degradation. The optimization of enzyme activity as crosslinked enzyme aggregases (CLEAs) without precipitant is important before use in any enzymatic process. In the proposed research, the immobilization of horseradish peroxidase in the form of crosslinked enzyme aggregates (HRP-CLEAs) without precipitant addition was optimized by three parameters full factorial experimental design at two levels and the degradation of an azo dye was tested. The optimal immobilization conditions were estimated as $0.06 \mathrm{mg}$ enzyme/mL (0.96 U), $3 \%$ (v/v, Glutaraldehyde)) cross-linker ratio, and $6 \mathrm{mg} / \mathrm{mL}$ Bovine Serume Albumine amount, respectively. The effects of variables were analysed by responce surface plots and the cross-linker ratio and albumin amount were found as important parameters while enzyme concentration effect was insignificant for the tested levels. The maximum CLEAs activity was $0.2188 \mathrm{U}$ and the kinetic parameters ( $\mathrm{Km}$ and Vmax) were $0.0314 \mathrm{mM}$ and $0.1044 \mathrm{mM} / \mathrm{min}$ while the calculated values for soluble enzyme were $0.06 \mathrm{mM}$ and $0.468 \mathrm{mM} / \mathrm{min}$, respectively. It was estimated that hydrogen peroxide decreased the enzyme aggregate activities at higher amounts than $0.012 \mathrm{mM}$. Under optimal conditions, The HRP-CLEAs completely oxidised the textile azo dye, Reactive Blue 160 within $90 \mathrm{~h}$ and it was found that decolorization time of azo dye was shortened at higher temperatures.
\end{abstract}

\author{
ARTICLE HISTORY \\ Received: 18.12 .2018 \\ Accepted: 22.02 .2021

\section{KEYWORDS} \\ Cross-Linked Enzyme \\ Aggregates, Horseradish \\ Peroxidase, Full Factorial \\ Design, Decolorization, Azo \\ dye
}

\section{INTRODUCTION}

The textile industry is the major sources of water pollution due to their easy use, cost effectiveness in synthesis, stability, variaty in colors, an better dyeing process conditions [1]. Textile industry wastewater are generally toxic due to the complex structure of the organic dyes they contain. Synthetic dyes are chemically diverse, with the commonly used in industry divided into those of azoic, triphenylmethane or heterocyclic/polymeric structures [2]. Discharging the textile industry wastewater to the environment can cause serious health and environmental problems. They are resistant to biological degradation due to their complex structure and synthetic nature, not being easily degraded in wastewater treatment plants [3].

Chemical and physical methods, that include adsorption, precipitation, chemical degradation, electrochemical, photochemical, biodegradation processes, were found effective at dye removal. But chemical methods results have some disadvantages such as the formation of large amounts of sludge, or short half-life of ozonation. The use of small-volume effluent and high costs were reported as other limits of physico-chemical methods [4]. For this reason, in addition to conventional treatment methods, the development of innovative and applicable technologies has become necessary. Decolorization of dyes by biological methods have been proposed as a cheaper and environmentally friendly. An oxidoreductase, Peroxidases produced by a number of plants and microorganisms catalyses the oxidation of organic substrates of aromatic materials [5]. They have molecular mass weight between 30-150 kDa.

Peroxidases are hydrogen peroxide $\left(\mathrm{H}_{2} \mathrm{O}_{2}\right)$ decomposing enzymes concomitant with the oxidation of wide range of phenolic (Figure 1) as well as non-phenolic substrates (RH).

To cite this article: Akpolat O, Ayhan F. 2021. Experimental Design Optimization and Decolorization of an Azo Dye by Cross-Linked Peroxidase Aggregates. Tekstil ve Konfeksiyon, 31(1), 34-42. 
They are widely found in nature such as bacteria, fungi, algae, plants and animals. The applications of peroxidases are in bioremediation, textile synthetic dye decolorization, polymer synthesis, paper and pulp industry, development of biosensor, diagnosis kits etc. [6, 7].

Fungi and their oxidative enzymes constitutes such as lignin peroxidase, laccase and manganese peroxidase [8[ were used as an alternative for treatment under aerobic conditions in the biological decolorization from waste [2]. Plant peroxidases regulates plant hormones, lignin biosynthesis and protective mechanism. The crude weed peroxidases, Portulacaoleracea, Sonchusoleraceus, Xanthium strumarium, Cyperusrotandus and Trianthemaportulacastrum was tested for catalyzing the degradation of phenolic compounds in wastewaters [9]. Many other plant sources for peroxidases production have been reported such as horseradish, turnip, tomato, cabbage, papaya, banana, and bare were also reported [5, 10]. Peroxidases from horseradish (HRP) is an enzyme has many application areas such as chemical, environmental, pharmaceutical and biotechnological industries such as industrial wastes [10]. The oxidation of synthetic textile dyes was performed with free [1, 11], carrier immobilized [12] or cross-linked form of HRP [13-15]. The use of enzymes in free form have some drawbacks due to their stability and reuse. Preparation of carrier-free immobilized enzymes by cross-linking of enzyme aggregates has become increasingly important. Cross-linked enzyme aggregates (CLEAs) present several advantages such as highly enzymatic activity, high stability, cost reducing by the lack of a support, and no previous purification of the enzyme. Peroxidase from Royal Palm leaves was used to decolorize azo dyes, methyl orange, methyl violet and Bismark. Optimized cross-linked enzyme aggregates (CLEAs) forms found stable against temperature, increasing their thermal stability, e.g. at $80{ }^{\circ} \mathrm{C}$ up to $5 \times 10^{3}$ fold with respect to the soluble form. The highest azo dye removal of almost $70 \%$ for methyl orange was obtained (13). HRP of Horseradish roots (Armoracia rusticana) fresh extract was immobilized in a form of cross-linked enzyme aggregates (CLEAs) with three different precipitans, acetone, ammonium-sulfate, and 2-propanol. Optimal conditions were reported as $\mathrm{pH} 4,30 \mathrm{mg} / \mathrm{L}$ dye concentration, and $0.1 \mathrm{mM}$ hydrogen peroxide concentration while 72.4 and $88.9 \%$ of
Acid Violet 109 (AV 109) was oxidized using HRP-CLEAs in a batch and packed bed reactor, respectively (14). Magnetic nanoparticles-Tannic acid-Cross-linked enzyma aggregates-peroxidase (MNPs-TA-CLEAs-peroxidase) were developed on starch and bovine serum albumin (BSA) precipited with ammonium sulphate to decolorize different types of dyes such as methylene blue, congo red, indigo carmine, and malachite green. The thermal deactivation constants were reported [15]. The formation of aggregates were achieved by using various precipitants such as sacetone, ammonium-sulfate, and 2-propanol. The optimization of aggregate formation with an experimental design method for process variables without any precipitant addition applied for decolorization of dyes were not reported until now.

In the study, the immobilization of peroxidase enzyme as cross-linked enzyme aggregates in the absence of any precipitant was optimized by experimental design aproach. Initial enzyme and proteic feeder concentrations, and crosslinker ratio were selected as the most important parameters that effecting enzyme activity. The number of experiments and the values of the variables were determined according to the full factorial experimental design (FFED) model in the frame of the upper and lower limits of these selected variables. The results of the experiments were evaluated by the response surface analysis (RSM) and the optimum variable values in the preparation of CLEAs of HRP were determined. The kinetic constants of free and CLEAs were estimated and decolorization of a diazo dye was investigated.

\section{MATERIALS AND METHODS}

Horseradish Peroxidase, Type II, and Bovin Serum Albumin (BSA) was purchased from SIGMA-Aldrich Chem. 25\%, glutaraldehyde (GA) solution $(25 \% \mathrm{v} / \mathrm{v}$ in water), (BAKER), hydrogen peroxide, $o$-dianisidine, potassyum permanganate (KIMETSAN) and sulphuric acid (95-98\%, BİRPA) were also perchased. Reactive Blue 160 azo dye was kindly supported by a local textile factory. All other reagents used were of analytical grade and used without further purification. Distilled water was used throughout the experiments.

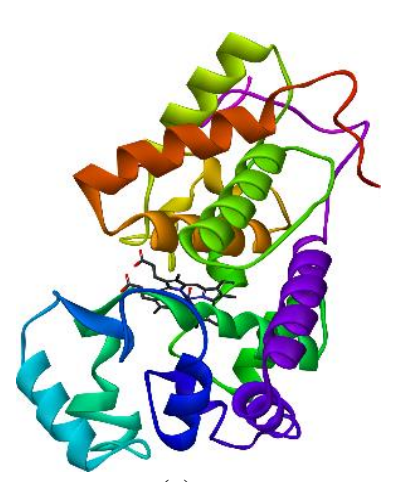

(a)

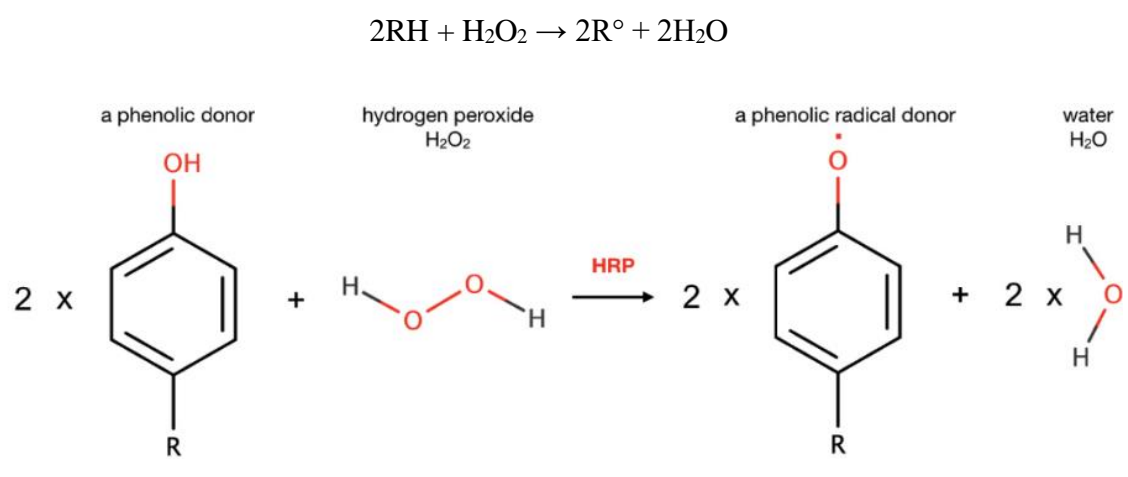

(b)

Figure 1. a) X-Ray modal and b) the oxidation of phenolic compaunds by the HRP enzyme 


\subsection{The synthesis of HRP-CLEAs}

Carrier free HRP aggregates were prepared based on previous works [16, 17]. BSA was added to the HRP enzyme solution of $80 \mu \mathrm{L}$ in $\mathrm{pH} 7$ borate buffer and allowed to be solved for $5 \mathrm{~min}$ at $100 \mathrm{rpm} / \mathrm{min}$ at room temperature. GA was added to reaction mixture at previously determined ratio and the final volume was completed to $1 \mathrm{~mL}$ with distilled water. The final mixture was stirred at the same ratio for $15 \mathrm{~min}$ and maintained at room temperature up to $2 \mathrm{~h}$. The solutions were kept at $4{ }^{\circ} \mathrm{C}$ overnight and aggregates were separated from reaction media by centrifugation at $7000 \mathrm{rpm} / \mathrm{min}$ at $4{ }^{\circ} \mathrm{C}$ for 15 min. The aggregates were washed with distilled water in order to remove the unreacted GA. The process was repeated four times to assure the cleaning. The morphology of HRP-CLEAs were studied by Olympus CX-31 optic microscope and LEO 1430 VP scanning electron microscope.

\subsection{Estimation of free and HRP-CLEAs activities}

The activity of HRP enzyme oxidases o-dianisidine in the presence of $\mathrm{H}_{2} \mathrm{O}_{2}$ and leads to the formation of coloured oxidized o-dianisidine and water [18, 19]. An enzyme unit $(1.0 \mathrm{U})$ is the enzyme amount which catalysis the oxidation of $1 \mu \mathrm{mol}$ of o-dianisidine. $\mathrm{HCl} \mathrm{min}{ }^{-1}$ at $25^{\circ} \mathrm{C}$ and $\mathrm{pH} 7.0$.

2.2.1 Free enzyme activity measurement: The mixture of $1 \mathrm{~mL}$ of $\mathrm{H}_{2} \mathrm{O}_{2}$ of $0,5 \mathrm{M}+1 \mathrm{~mL}$ of o-dianisidin of $6.0 \mathrm{mM}$ was prepared and the enzyme solution of $0.5 \mathrm{mg} / \mathrm{L} \mathrm{HRP}$ of $25 \mu \mathrm{L}$ volume was slowly injected. A sample of $1 \mathrm{~mL}$ was taken and added to $10 \mathrm{~mL}$ of $\mathrm{H}_{2} \mathrm{SO}_{4}$ (5\% sulphuric acid solution) and redox titration was performed with $0.020 \mathrm{M}$ $\mathrm{KMnO}_{4}$ until purple-red color formation occurs. The unreacted $\mathrm{H}_{2} \mathrm{O}_{2}$ concentration $(\mathrm{g} / \mathrm{L}$ ) was calculated from the volume of the spended $\mathrm{KMnO}_{4}$ multiplied by 1.7 . Converted $\mathrm{H}_{2} \mathrm{O}_{2}$ anount after catalysis was estimated by the subtraction from initial amount. The procedure was repeated until 5 min with different reaction media and each experiment was repeated at least three times.

2.2.2 HRP-CLEAs enzyme activity measurement: The aggregates were placed on a gauze and bonded. The fixed material soaked to reaction media of $\mathrm{H}_{2} \mathrm{O}_{2}$ and o-dianisidin given above. After that the same activity procedure in case of free enzyme was followed.

The CLEAs activities of all aggregates were estimated for six $\mathrm{H}_{2} \mathrm{O}_{2}$ concentrations $(0.012,0.018,0.024,0.03,0.036$, and $0.042 \mathrm{mM}$ ). The activity was determined at each $1 \mathrm{~min}$ time interval and followed for $5 \mathrm{~min}$. Linearization of the results was applied and the slope of maximum regression coefficient at least three data was reported as CLEAs activity of the assayed aggregate for one $\mathrm{H}_{2} \mathrm{O}_{2}$ concentration. The activity values of eight aggreate for six different substrate concentrations were estimated at different time intervals for a constant $\mathrm{H}_{2} \mathrm{O}_{2}$ concentration.

The kinetic parameters, $\mathrm{Km}$ and Vmax were determined from the Lineveaver-Burk plot of activity values for various o-dianisidine. $\mathrm{HCl}$ concentrations at $\mathrm{pH} 7.0$ and $0.012 \mathrm{mM}$ $\mathrm{H}_{2} \mathrm{O}_{2}$.

\subsection{Optimization studies}

The full factorial design of two-level for three variables $\left(2^{\mathrm{k}}=2^{3}=8\right)$ at low $(-1)$ and high $(+1)$ settings was given in Table 1(a). The parameter values of eight aggregate were estimated. The following model was related with the selected variables for the responce, activity of HRPCLEAs:

Table 1. a) Levels and their experimental values of variables of full factorial design, b) Two-level full factorial design table for three variables

\begin{tabular}{|c|c|c|c|c|c|}
\hline \multicolumn{4}{|c|}{ Variables } & Level (-1) & Level (+1) \\
\hline \multicolumn{3}{|c|}{ Enzyme concentration $(\mathrm{mg} / \mathrm{mL})$} & (EC) & 0.04 & 0.06 \\
\hline \multicolumn{3}{|c|}{ Cross-linker ratio $(\mathrm{h} / \mathrm{h})$} & (CL-R) & 1 & 3 \\
\hline \multicolumn{3}{|c|}{ Proteic feeder concentration $(\mathrm{mg} / \mathrm{mL})$} & $(\mathbf{P F})$ & 2 & 6 \\
\hline (b) & Aggregate No & \multicolumn{2}{|c|}{$\mathbf{E C}(\mathrm{mg}$ enz./mL) } & CL-R \%(h/h) & PF $(\mathrm{mg} / \mathrm{mL})$ \\
\hline & 1 & \multicolumn{2}{|c|}{0.04} & 1 & 2 \\
\hline & 2 & \multicolumn{2}{|c|}{0.06} & 1 & 2 \\
\hline & 3 & \multicolumn{2}{|c|}{0.04} & 3 & 2 \\
\hline & 4 & \multicolumn{2}{|c|}{0.06} & 3 & 2 \\
\hline & 5 & \multicolumn{2}{|c|}{0.04} & 1 & 6 \\
\hline & 6 & \multicolumn{2}{|c|}{0.06} & 1 & 6 \\
\hline & 7 & \multicolumn{2}{|c|}{0.04} & 3 & 6 \\
\hline & 8 & \multicolumn{2}{|c|}{0.06} & 3 & 6 \\
\hline
\end{tabular}


$y=b_{0} x_{0}+b_{1} x_{1}+b_{2} x_{2}+b_{3} x_{3}+b_{12} x_{1} x_{2}+b_{13} x_{1} x_{3}+b_{23} x_{2} x_{3}+b_{123} x_{1} x_{2} x_{3}$

where $\chi_{1}, \chi_{2}$, and $\chi_{3}$ represent the independent varibles, enzyme concentration, cross-linker ratio, and proteic feeder; $b_{0}$ is the constant; $b_{i}, b_{i i}$, and $b_{i i i}$ are constants of single parameter, double and triple interaction of parameters, Enzyme activity was denoted by $y[20,21]$. The FFED was applied using Design Expert software (stat ease 7.0.0 version) and RSM using FFEX was applied to optimize enzyme activity using significant parameter value.

\subsection{Decolorization experiments}

The industrial diazo dye gives the absorption peak at 616 $\mathrm{nm}$. The concentration of reactive blue was prepared as $10^{-6}$ $\mathrm{M}$ in distilled water and $10 \mathrm{ml}$ reaction media of azo dye treated with gauzed HRP-CLEAs that showed the highest activity. The experiment was continued $90 \mathrm{~h}$ and \% decolorization was reported for certain time intervals. The experiments were again repeated more than two times and average values were reported. The decolorization percentage was calculated by;

$\mathrm{D} \%=\frac{\mathrm{Abs}_{\text {initial }}-\mathrm{Abs}_{\text {final }}}{\mathrm{Abs}}$

$\mathrm{Abs}_{\text {initial }}$

\section{RESULTS AND DISCUSSION}

In this study, CLEAs were prepared by cross-linking with a bifunctional cross-linker, GA in the presence of proteic feeder, BSA. The three parameters, enzyme and proteic feeder concentrations, and cross-linker ratio were selected as parameters of the full factorial experimental design.

\subsection{Application of two-level full factorial design in HRP-CLEAs formation and Optimization studies}

Enzyme and proteic feeder concentrations, and cross-linker ratios were estimated in two levels according to full factorial experimental design. Table 2 gives the activities of each HRP-CLEAs for various $\mathrm{H}_{2} \mathrm{O}_{2}$ concentration values. The full factorial experimental design for three variables at two levels needs to prepare eight CLEAs. The levels given in Table 1B were used to synthesize these aggregates each has different parameter values. Aggregate No.4 with enzyme concentration of $0.06 \mathrm{mg}$ enzyme $/ \mathrm{mL}$, proteic feeder with $2 \mathrm{mg} / \mathrm{mL}$ and cross-linker ratio of $3 \% \mathrm{v} / \mathrm{v}$ showed the highest CLEAs activity when $\mathrm{H}_{2} \mathrm{O}_{2}$ concentration of $0.012 \mathrm{mM}$ was used. The slope of linear equation in Figure 2 gives the activity of aggregate No. 4 as $0.2188 \mathrm{mM} / \mathrm{min}$. The same procedure was applied for each aggregate and the slope of the equations with correlation coefficients greater than 0.99 were selected as activity values. The effect of $\mathrm{H}_{2} \mathrm{O}_{2}$ concentration was investigated and the calculated activity values for other aggregates treated with $0.012,0.018,0.024,0.03,0.036$, and 0.042 $\mathrm{mM} \mathrm{H}_{2} \mathrm{O}_{2}$ was also shown in Figure 3.

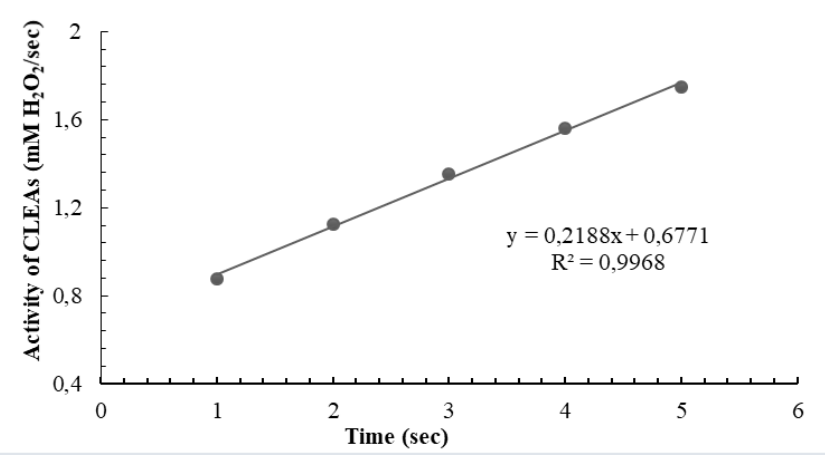

Figure 2. Activity of HRP-CLEAs No 4 versus time

The same number of CLEAs has the highest activity also for $0.018 \mathrm{mM}$ of $\mathrm{H}_{2} \mathrm{O}_{2}$ with $0.1458 \mathrm{mM} / \mathrm{s}$ enzymatic activity. CLEAs No. 1 has the less (level-1) enzyme amount, cross-linker ratio and proteic feeder concentration and its enzymatic activity was the highest at $0.030 \mathrm{mM}$ $\mathrm{H}_{2} \mathrm{O}_{2}$ concentration. Aggregat No. 7 and 8 contain the highest cross-linker ratio and proteic feeder concentrations and the calculated activies were less than other aggregates. Additionally, the lowest CLEAs at 0.012, 0.018, and 0.03 $\mathrm{mM} \mathrm{H} \mathrm{H}_{2} \mathrm{O}_{2}$ concentrations were analysed. Activity values of Agg. No: 6 for 0.024, 0.036, and $0.042 \mathrm{mM} \mathrm{H} \mathrm{O}_{2}$ resulted with the highest activity values between other aggregates.

Table 2. Calculated activity values of all HRP-CLEAs with $\mathrm{R}^{2}>0.99$

\begin{tabular}{|c|c|c|c|c|c|c|c|c|}
\hline $\begin{array}{l}\text { Agregate No. } \\
\text { Concentration } \\
(\mathbf{m M})\end{array}$ & $\mathbf{1}$ & $\mathbf{2}$ & $\mathbf{3}$ & $\mathbf{4}$ & $\mathbf{5}$ & $\mathbf{6}$ & $\mathbf{7}$ & $\mathbf{8}$ \\
\hline $\mathbf{0 . 0 1 2}$ & 0.1711 & 0.1625 & 0.1708 & $\mathbf{0 . 2 1 8 8}$ & 0.2167 & 0.1938 & 0.1533 & 0.1375 \\
\hline $\mathbf{0 . 0 1 8}$ & 0.0972 & 0.1056 & 0.1306 & $\mathbf{0 . 1 4 5 8}$ & 0.1444 & 0.1292 & 0.1234 & 0.0917 \\
\hline $\mathbf{0 . 0 2 4}$ & 0.0341 & 0.0698 & 0.0344 & 0.0542 & 0.0509 & $\mathbf{0 . 0 5 9 5}$ & 0.0501 & 0.0687 \\
\hline $\mathbf{0 . 0 3 0}$ & $\mathbf{0 . 0 6 5 7}$ & 0.0458 & 0.0146 & 0.0279 & 0.0637 & 0.0494 & 0.0401 & 0.055 \\
\hline $\mathbf{0 . 0 3 6}$ & 0.0296 & 0.0573 & 0.0215 & 0.0114 & 0.0215 & $\mathbf{0 . 0 5 8 2}$ & 0.0312 & 0.0507 \\
\hline $\mathbf{0 . 0 4 2}$ & 0.027 & 0.238 & 0.0333 & 0.0327 & 0.0274 & $\mathbf{0 . 0 6 6 8}$ & 0.0616 & 0.0446 \\
\hline
\end{tabular}




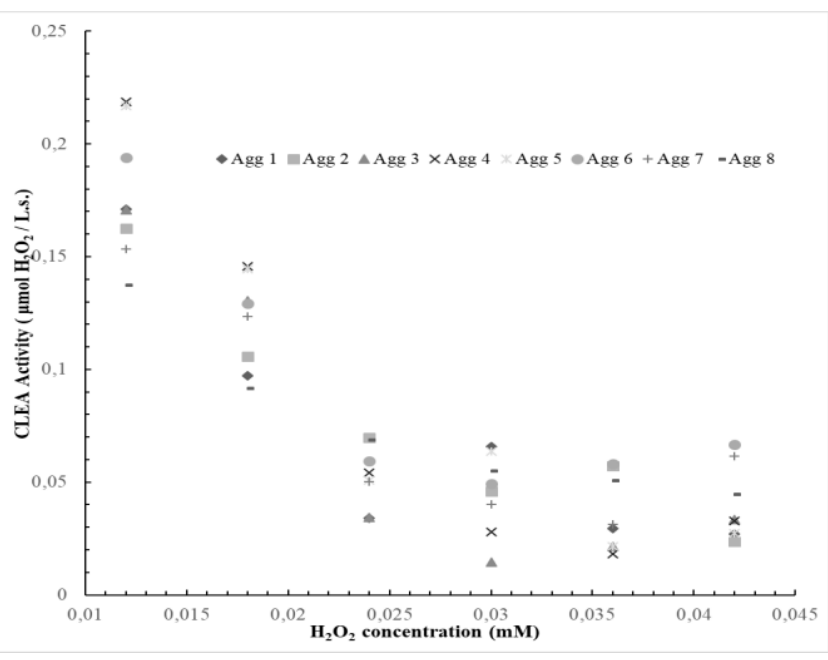

Figure 3. Activity change of HRP-CLEAs with $\mathrm{H}_{2} \mathrm{O}_{2}$ concentrations

The CLEAs with number 6 has the lowest cross-linker ratio whilst the enzyme and and proteic feeder concentrations are in level +1 according to design. Also substrate concentrations was the highest two tested values. It must be noted that the biggest activity values with aggregates other than Agg. No. 4 were estimated for -1 level cross-linker ratios when hydrogen peroxide concentration increased. The behaviour of HRP-CLEAs activities tends to decrease as substrate concentration increases which greatly obeys the graphical presentation of substrate inhibition [22]. This may be the result of the inhibition effect of $\mathrm{H}_{2} \mathrm{O}_{2}$ for the enzyme amounts in carrier-free CLEAs. Figure 4 gives the activity change of each aggregate at various $\mathrm{H}_{2} \mathrm{O}_{2}$ concentrations.
The BSA concentration, proteic feeder seems to be an important parameter in order to decrease the inhibition of $\mathrm{H}_{2} \mathrm{O}_{2}$ or degradation products since aggregates with No:6, 7 , and 8 resulted with higher activity values at high $\mathrm{H}_{2} \mathrm{O}_{2}$. This behavior changes for low proteic feeder concentrations and enzyme amount became more important parameter in aggregate structure.

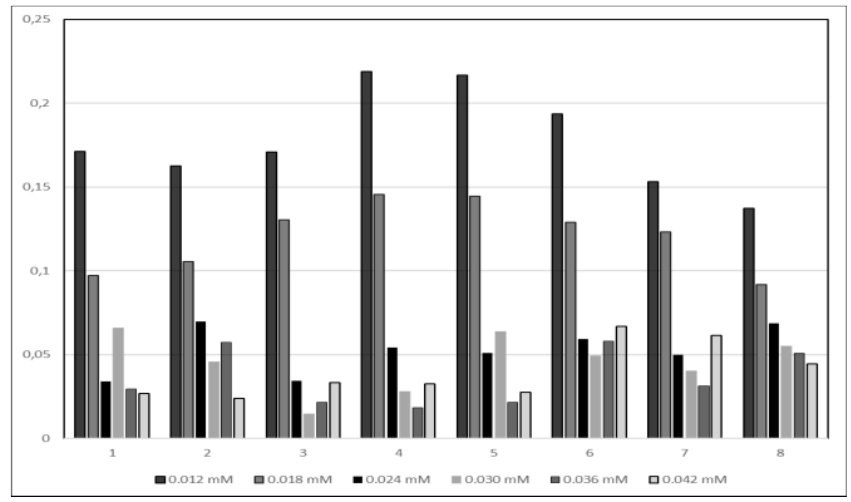

Figure 4. The activity change of each HRP-CLEAs at different $\mathrm{H}_{2} \mathrm{O}_{2}$ concentrations

Additionally, the optical microscope images of Aggregate no.4 at different magnifications was shown in Figure 5. SEM image of HRP-CLEAs shown in Figure 6 indicated an amorphous structure.

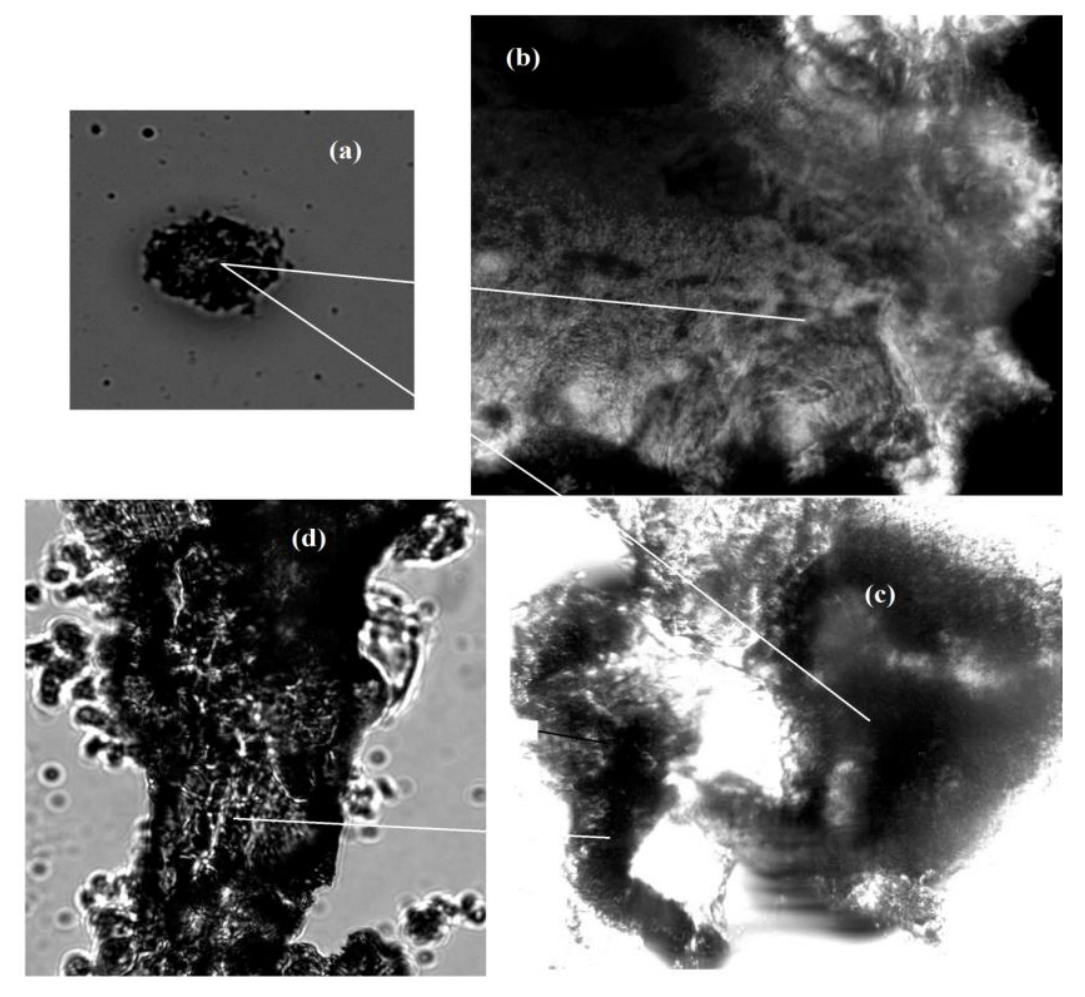

Figure 5. The optical microscopy images of Agg. No. 4. with a) x10, b) x60, c) x40, d) x40 magnifications 


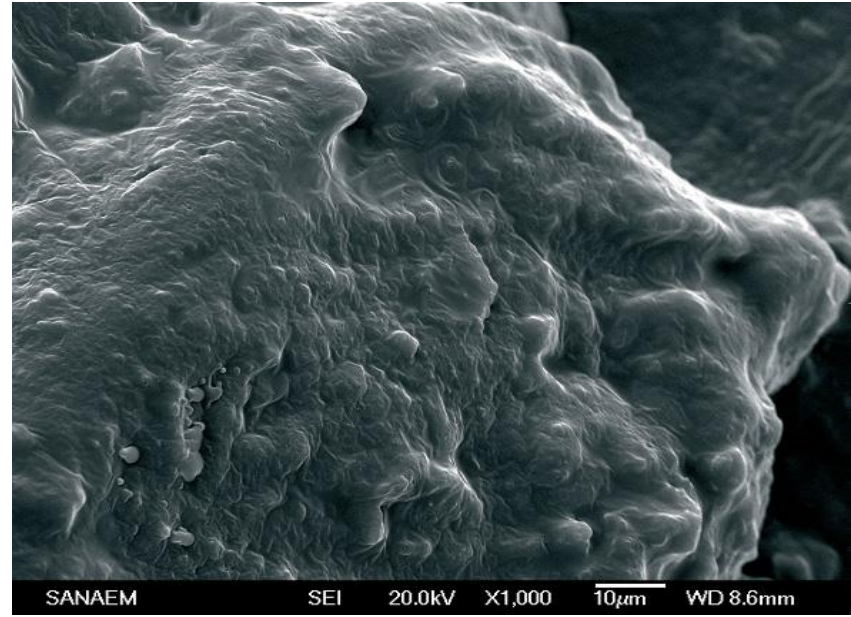

Figure 6. The SEM image of HRP Aggregate no.4

Experimental design (Table 1(b)) was performed and the results were evaluated using Design Expert program. Analysis of variance was used to calculate the significance for Aggregate no: 4 which showed the highest enzyme activity at $0.012 \mathrm{mM} \mathrm{H}_{2} \mathrm{O}_{2}$ concentration. The results shows that enzyme concentration has insignificant effect, but cross-linker ratio and proteic feeder concentration effect were also not very high but cross-linker has the biggest effect followed by effect of proteic feeder. ANOVA analysis of HRP-CLEAs for the proposed model was resulted with high correlation coefficient value. The effect of enzyme concentration was negligible and cross-linker and proteic feeder effect were approximately in the same order. If the selected levels of enzyme amounts was smaller and higher than proposed level quantities, the effect of enzyme concentration may be greater.

Responce surface graph of the effects of variables (proteic feeder and cross-linker ratio) was given in Figure 7. Figure $7(\mathrm{a})$ is the responce surface at $0.05 \mathrm{mg} / \mathrm{mL}$ enzyme concentration and has neither optimum value nor peak. When enzyme concentration was fixed at -1 level or +1 levels, responce surfaces resulted with two peaks; one at high proteic feeder and low cross-linker and the other at low proteic feeder and high cross-linker ratio, respectively (Figures 7(b) and 7(c)). These results indicate the crosslinker effect on protein structures, which may cause significant activity changes in final product.
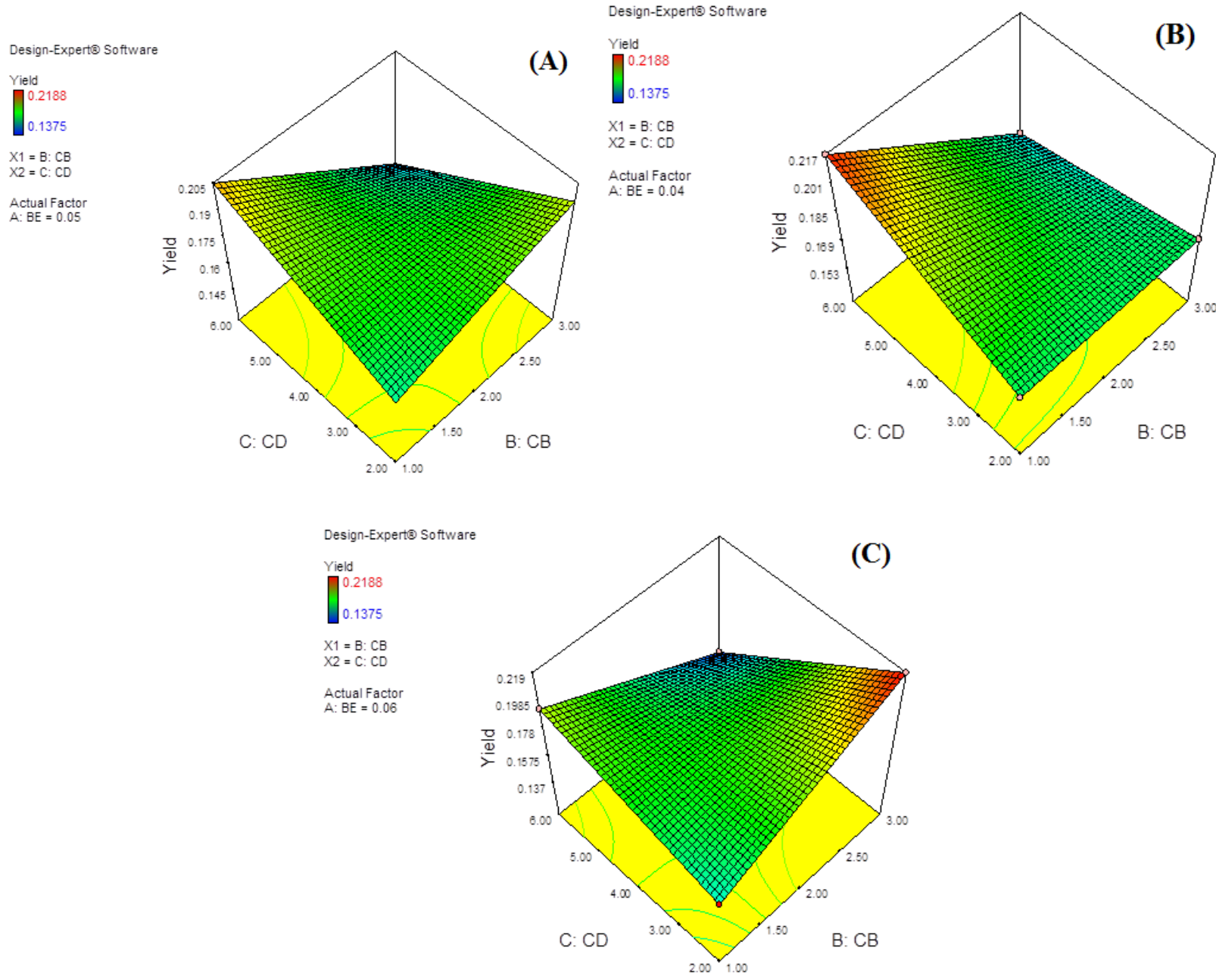

Figure 7. Responce surface plots of cross-linker ratio and proteic feeder effects on HRP-CLEAs activity (Yield) (A:BE Enzyme concentration, B:CB cross-linker ratio, C:CD proteic feeder). Enzyme concentration was fixed at a) $0.05 \mathrm{mg} / \mathrm{L} ; \mathrm{b}) 0.04 \mathrm{mg} / \mathrm{L} ; \mathrm{c})$ $0.06 \mathrm{mg} / \mathrm{L}$ 


\subsection{Kinetic parameters of free and immobilized HRP}

Lineweaver-Burk plot was used to determine the kinetic parameters of $\mathrm{Km}$ and $\mathrm{Vm}$ for free and CLEAs. A new aggregate was synthesized with $0.05 \mathrm{mg} / \mathrm{mL}$ enzyme concentration, $\% 2$ cross-linker ratio and $5 \mathrm{mg}$ proteic feeder which are the middle values of full factorial design. The parameter values were calculated at o-dianisidin of $6.0 \mathrm{mM}$ and $0.001-0.012 \mathrm{mM} \mathrm{H} \mathrm{H}_{2} \mathrm{O}_{2}$ concentrations, respectively. Kinetic parameters of free HRP enzyme was given in Table 3.

Table 3. Calculated kinetic parameter values of free and HRPCLEAs

\begin{tabular}{|l|l|l|}
\hline Kinetic parameters & $\mathrm{Km}(\mathrm{mM})$ & $\mathrm{Vm}(\mathrm{mM} / \mathrm{min})$ \\
\hline Free enzyme & 0.06 & 0.468 \\
\hline Immobilized enzyme & 0.0314 & 0.1044 \\
\hline
\end{tabular}

Nearly the double decrease in $\mathrm{Km}$ values indicates the lessening of affinity of enzyme to substrate. Maksimum enzyme activity was also decreased about four times compared with free enzyme which may be the result of conformational change in immobilization process. $\mathrm{Km}$ value of free and horseradish peroxidase on PAN-beads was $0.288 \mathrm{mM} 1.458 \mathrm{mM}$, respectively which was 5 folds. The maximum activity, Vmax of immobilized horseradish peroxidase $\left(14.2 \mathrm{mM} \mathrm{min}^{-1}\right)$ was about 6 folds to free horseradish peroxidase $\left(89.7 \mathrm{mM} \mathrm{min}^{-11}\right)$ [25]. Lignin Peroxidase was entrapped in Ca-alginate beads and used in decolorization of Sandal-fix Red C4BLN, Sandal-fix Turqblue GWF, Sandal-fix Foron Blue E2BLN, Sandal-fix Black CKF and Sandal-fixGolden yellow CRL dyes. Entrapment enhanced substrate affinity from $0.25 \mathrm{mM}$ to $0.30 \mathrm{mM}$ and hence catalytic activity was found to be improved (initial: $586.7 \mu \mathrm{mol} / \mathrm{min}$, after entrapment: 868.6 $\mu \mathrm{mol} / \mathrm{min}$ ) [3]. These results confirm that cross-linking affected the enzyme structure and conformational changes occured in such a way that resulted with decrease of activity. The parameters of immobilization conditions like cross-linker and proteic feeder besides steric hindrance and diffusion limitations change the conformation of crosslinked enzyme aggregates compared with free enzyme.

\subsection{Decolorization of Reactive Blue 160}

The aggregate no.4 of full factorial design which resulted with the highest activity was treated with dye solution of $10^{-6} \mathrm{M}(1.309 \mathrm{mg} / \mathrm{L})$ and decolorization was followed by spectrophotometrical measurements. The dye concentration was arranged to perform spectrophotometric measurements without dilution. The decolorization conditions of $\mathrm{pH} 7$, dye concentration $1.309 \mathrm{mg} \mathrm{L}^{-1}$, and hydrogen peroxide concentration $0.012 \mathrm{mM}$, complete decolorization of reactive blue dye 160 was resulted after $90 \mathrm{~h}$ at $25{ }^{\circ} \mathrm{C}$. Table 4 gives the decolorization percentage at different time intervals. The oxidation of dye was also tested at 40 ,
50, and $60{ }^{\circ} \mathrm{C}$, respectively. The complete decolorization was determined in 62, 58, and $49 \mathrm{~h}$, respectively (data not given). The results also indicate the thermal resistance of enzyme aggregates.

Table 4. Decolorization $\%$ of Reactive Blue azo dye of HRPCLEAs No 4 with time at $25^{\circ} \mathrm{C}$

\begin{tabular}{|c|c|}
\hline Time (hr) & \% Decolorization* \\
\hline 0 & 0 \\
\hline 8 & 16.5 \\
\hline 16 & 22.2 \\
\hline 24 & 29.4 \\
\hline 32 & 36.6 \\
\hline 40 & 43.9 \\
\hline 48 & 52.6 \\
\hline 56 & 63.5 \\
\hline 64 & 71.0 \\
\hline 72 & 82.2 \\
\hline 80 & 90.2 \\
\hline 90 & 100 \\
\hline
\end{tabular}

*average of three experimental results.

The synthetic Reactive blue dyes have very different structures and molecular weights. The bounding of the functional reactive groups also determines the dying capacity and decolorization. The Rective Blue 160 has the molecular weight of $1309.831 \mathrm{~g} / \mathrm{mol}$ and has two $1,3,5-$ triazine, nitrogen containing heterocycles [27].

Different decolorization research results of azo dyes were reported with CLEAs of peroxidase [1, 13-15,23-26, 2830]. The formation of aggregates were all carried out in the presence of precipitant either with alcohol, acetone, ammonium-sulfate, or 2-propanol. Decolorization of Methyl orange and Acid Violet 109 was tested with HRPCLEAs and results indicates the importance of reaction conditions. HRP-CLEAs were synthesized for the oxidation of methyl orange, methyl violet and ismark Brown. Methyl orange was the most effectively removed azo dye at $\mathrm{pH} 2.7$ and under mild temperature [13]. Under optimal conditions (pH 4, dye (Acid Violet 109 (AV 109)) concentration 30 $\mathrm{mgL}^{-1}$, hydrogen peroxide concentration $0.1 \mathrm{mM}$ ), 72.4 and $88.9 \%$ of dye was oxidized using $0.1 \mathrm{U}$ of HRP-CLEAs in a batch and packed bed reactor [14]. Small amount of the functionalized magnetic cross linked peroxidase aggregates were used to decolorize different dyes. The extraction parameters of peroxidase activity was optimized [15]. The preparation of CLEAs of fungi laccases were optimized for bifunctional reagent (glutaraldehyde) concentration, time of cross-linking and temperature of cross-linking [25].

On the other hand, decolorization of Reactive Blue dye 160 was performed with free, immobilized enzymes, and bacterial strains. Recently, the enzymatic decrease of dye color was tested with $0.1 \mathrm{~mL}$ of enzyme extract 29.85 U.mL ${ }^{-1}$ of horseradish peroxidase. The maximum decolorization was $69.0 \pm 0.005 \%$ for Reactive Blue 21(RB 21 ) in $1 \mathrm{~h}$ and $\mathrm{pH} 4$. The optimum removal for $\mathrm{RB} 21$ of 40 
$\pm 0.18 \mathrm{mg} . \mathrm{L}^{-1}$ was obtained in $1 \mathrm{~h}$ when dye concentration of $60 \mathrm{mg} . \mathrm{L}^{-1}$ was used. In the studies with dye RB 21 the highest removal was obtained at $20^{\circ} \mathrm{C}, 79.0 \pm 0.007 \%$; however, at $30^{\circ} \mathrm{C}$ the removal was reported as $77.0 \% \pm 0.0016$ [11]. The co-immobilized chloroperoxidase (CPO) and horseradish peroxidase (HRP) on $\mathrm{ZnO}$ nanowires/macroporous $\mathrm{SiO}_{2}$ composite support were obtained by cross-linking. For the decolorization of two azo dyes (Acid Blue 120 and Direct Black 38), the coimmobilized CPO (60\%)/HRP (40\%) exhibited high catalytic activity over very wide ranges of $\mathrm{pH}$, temperature and $\mathrm{H}_{2} \mathrm{O}_{2}$ concentration. The total specific activity up to 15.7 U per mg support was obtained and decolorization was completed within $3 \mathrm{~h}$ of reaction for both azo dyes [24]. The bacterial strain, Microbacterium sp. B12 Mutant isolated from a textile industry soil was used in the decolorizing industrial Reactive Blue 160 (RB160) dye. A $96 \%$ decolorization efficiency of $250 \mathrm{mg} / \mathrm{l}$ was reported in microaerobic conditions with temperature $35 \pm 2{ }^{\circ} \mathrm{C}$ and $\mathrm{pH}$ 5.0 in $24 \mathrm{~h}$. When physical and chemical mutagens were used to improve the decolorization efficiency, mutant strain showed the complete reduction in $12 \mathrm{~h}$ [26]. In vitro decolorization and remediation of the textile RB160 dye was carried out with tissue cultured plants of the seeds of $T$. Patula. After 4 days of incubation time, a $90 \%$ decolorization was conformed by diffirent analytical analysis methods. It was declared that the presence of lignin peroxidase, tyrosinase, laccase and NADH-DCIP reductase found in root tissues of the plants are responsible for the remediation of dye [27]. The mixed cultures BDN consisted of eight bacterial strains was evaluated in degradation of diazo dye, RB160. The complete decolorization and degradation of RB160 (100 mg/L) was completed within 4 $\mathrm{h}$ along with co-metabolism of yeast extract $(0.5 \%)$ in minimal medium. The reductase enzymes symmetrically cleaved RB160 and oxidative enzymes further metabolised the degraded products and five different intermediates were identified using FTIR, HNMR and GC-MS. Lignin peroxidase, Laccase, Tyrosinase, Azoreductase, and $\mathrm{NADH}-\mathrm{DCIPc}$ were estimated as oxido-reductive enzymes in mixed culture BDN [28].

It may be concluded that enzyme decolorization of textile dyes were evaluated with the use of free, immobilized, and aggregate formation methods of HRP and the microbial cultures were the most selected method in the oxidation of RB 160 dye. This study proposed another enzymatic treatment and removal method of RB 160 dye which is an important effluent of textile industry.

\section{CONCLUSIONS}

The preparation of HRP-CLEAs without precipitant were optimized by changing the parameter values according to full factorial experimental design where the parameters were selected as concentrations of enzyme and proteic feeder, and cross-linker ratio. The evaluation of the responce surface analysis gives the results that enzyme concentration was less significant than proteic feeder concentration and cross-linker ratio in the anticipated parameter ranges. The role of $\mathrm{H}_{2} \mathrm{O}_{2}$ in oxidative process of different aggregate structures was evaluated as an effective reaction factor on the enzymatic activity process. Decolorization of a diazo dye was succesfully realized and the research can be conducted for other types of dyes and industrial conditions to extend the effectiveness of the HRP-CLEAs.

\section{Acknowledgment}

This work is supported by the Scientific Reseach Projects Coordination Office of Muğla Sıtkı Koçman University (Grant No s 12/31) for financial assistance.

\section{Conflict of Interest}

The authors have no conflict of interests to declare.

\section{REFERENCES}

1. Da Silva MR, de Sà LRV, Russo C, Scio E, Ferreira-Leitao VS. 2010 The use of HRP in decolorization of reactive dyes and toxicological evaluation of their products. SAGE-Hindawi Access to Research Enzyme Research, Article ID 703824, 7 pages http://dx.doi.org/10.4061/2010/703824.

2. Levin L, Forchiassin F, Viale A. 2005. Ligninolytic enzyme production and dye decolorization by Trametes trogii: application of the Plackett-Burman experimental design to evaluate nutritional requirements. Process Biochemistry 40, 1381-1387.

3. Shaheen R, Asghera M, Hussaina F, Bhatti HN. 2017. Immobilized lignin peroxidase from Ganoderma lucidum IBL-05 with improved dye decolorization and cytotoxicity reduction properties. International Journal of Biological Macromolecules 103, 57-64.

4. Robinson T, McMullan G, Marchant R, Nigam P. 2001. Remediation of dyes in textile effluent: a critical review on current treatment technologies with a proposed alternative. Bioresource Technology 77 , 247-255.

5. Rathnamsamy S, Singh R, Auxilia R, Vedhahari BN. 2014. Extraction of peroxidasese from various plant sources and its biodegradation studies on phenolic compounds. BioTechnology 9(4), 160-165.

6. Pandey VP, Awasthi M, Singh S, Tiwari S, Dwivedi UN. 2017. A comprehensive review on function and application of plant peroxidases. Biochemistry \& Analytical Biochemistry 6, 1-16.

7. Kawakita H. 2012. Metal recovery using polyphenols prepared by enzymatic reactions of horseradish peroxidase. Science and Technology 2 (1), 25-29

8. Kariminiaae-Hamedaani H-R, Sakurai A, Sakakibara M. 2007. Decolorization of synthetic dyes by a new manganese peroxidase producing white rot fungus. Dyes and Pigments 72, 157-162.

9. Hamad IS, Ahmed A, Azim A. 2013. Biodegradation of phenols in wastewater using crude peroxidases five weed plants. Journal of Chemical and Pharmaceutical Research 5(4), 60-65. 
10. Bansal P, Dhir A, Prakash NT, Sud D. 2011. Environmental remediation of wastewater containing azo dyes with a heterostructured nanophotocatalyst. Indian Journal of Chemistry 50A, 991-995.

11. Farias S, de Oliveira D, Ulson de Souza AA, Guelli SMA, de Souza U, Morgado AF. 2017. Removal of reactive blue 21 and Reactive red 195 dyes using horseradish Peroxıdase as catalyst. Brazilian Journal of Chemical Engineering, 34(03), 701-707.

12. Yinca Z, Yan L, Xueyong G, Qiao W, Xiaoping X. 2017. Decolorization of Color Index Acid Orange 20_buffer solution using horseradish peroxidase immobilized on modified PAN-beads. RSC Advances 7, 18976-18986.

13. Grateron C, Barbosa O, Ruedaa N, Ortiz-L'opez C, Torres R. 2007 Azo dye decolorization by optimized cross linked enzyme aggregates (CLEAs) of a royal palm (Roystonea regia) peroxidase. Abstracts / Journal of Biotechnology 131S, S74-S97.

14. Sekuljica NZ, Prlainovic NZ, Jakovetic SM, Grbavcic SZ, Ognjanovi ND, Knezevi-Jugovic ZD, Mijin DZ. 2016. Removal of anthraquinone dye by cross-linked enzyme aggregates from fresh horseradish extract. Clean - Soil, Air, Water 44 (7), 891-900.

15. Mehde AA. 2019. Development of magnetic cross-linked peroxidase aggregates on starch as enhancement template and their application for decolorization. International Journal of Biological Macromolecules 131, 721-733.

16. Topçular C, Ayhan H. 2008. Carrier free cross-linked peroxidase aggregates synthesis and characterization. Hacettepe Journal of Biology \& Chemistry 36(3), 255-261.

17. Ayhan F, Doğaç Y, Ayhan H. 2011. Cross-linked glucose oxidase aggregates: synthesis and characterization. Hacettepe Journal of Biology \& Chemistry 39(3), 241-251.

18. Claiborne A, Fridovich I. 1979. Chemical and enzymatic intermediates in the peroxidation of o-dianisidine by horseradish peroxidase. 1. Spectral properties of the products of dianisidine oxidation. Biochemistry 18(11) 2325

19. Bania I, Mahanta R. 2012. Evaluation of peroxıdases from varıous plant sources. International Journal of Scientific and Research Publications 2(5), 1-5.
20. Montgomery DC, George CR. 2003. Applied Statistics and Probability for Engineers, $3^{\text {rd }}$ edition, Singapore: John Wiley \& Sons.

21. Engineering Statistics Handbook, Improve-Process Improvement, Full Factorial Designs, https://www.itl.nist.gov/div898/handbook/pri/ section3/pri3332.htm, Date created: 6/01/2003, Last updated: 10/30/2013, (Accessed 06/08/2018).

22. Bailey JE, Ollis DF. 1986. Biochemical Engineering Fundamentals. Singapore: McGraw-Hill Book Company.

23. Mohan SV, Prasad KK, Rao NC, Sarma PN. 2005. Acid azo dye degradation by free and immobilized horseradish peroxidase (HRP) catalyzed process. Chemosphere 58, 1097-1105.

24. Katheresan V, Kansedo J, Lau SY. 2018. Efficiency of various recent wastewater dye removal methods: A review. Journal of Environmental Chemical Engineering 6, 4676-4697.

25. Vršanská M, Vob`erková S, Jiménez AMJ, Strmiska V, Adam V. 2018. Preparation and optimisation of cross-linked enzyme aggregates using native isolate white rot fungi Trametes versicolor and fomes fomentarius for the decolourisation of synthetic dyes. International Journal of Environmental Research and Public Health 15(1), 1-15.

26. Jin $\mathrm{X}$, Li S, Long N, Zhang R. 2018. A robust and stable nanobiocatalyst by co-immobilization of chloroperoxidase and horseradish peroxidase for the decolorization of azo dyes. Journal of Chemical Technology \& Biotechnology 93, 489-497.

27. Reactive Blue 160, 2018, December 1, Retrieved from http://www.worlddyevar_ety.com/react_ve-dyes/react_ve-blue160.html 1/

28. Roat C, Kadam A, Patel T, Dave S. 2016. Biodegradation of diazo dye, reactive blue 160 by isolate Microbacterium sp. B12 mutant: identification of intermediates by LC-MS. International Journal of Current Microbiology and Applied Sciences 5(3), 534-547.

29. Patil A. V., Jadhav J. P., 2013, Evaluation of phytoremediation potential of Tagetes patula L. for the degradation of textile dye Reactive Blue 160 and assessment of the toxicity of degraded metabolites by cytogenotoxicity. Chemosphere 92, pp: 225-232.

30. Balapure KH, Jain K, Chattaraj S, Bhatt NS, Madamwar D. 2014. Cometabolic degradation of diazo dye-Reactive blue 160 by enriched mixed cultures BDN. Journal of Hazardous Materials 279, 85-95. 